\title{
From the Augustan Principate to the invention of the age of Augustus ${ }^{1}$
}

\section{ALISON E. COOLEY}

\begin{abstract}
This paper explores alternatives to analysing the political impact of Augustus in terms of the establishment of a new constitutional structure, the Augustan Principate. It starts by showing how the word principatus changed over time and explores the significance of the term statio. It considers how contemporaries viewed the political changes that occurred during Augustus' lifetime, analysing the ways in which power at Rome became increasingly embodied in the person of Augustus himself. It suggests that there was an increasing recognition that Augustus was an exceptional individual, whose position in the state was supported by powers granted formally by senatorial decree and popular vote as well as informally by acclamation, but whose authority was ultimately a personal quality, supported by the gods, and predestined by birth. It traces the ways in which Augustus' rule became increasingly personalised, with the result that one of the main challenges faced by Tiberius in A.D. 14 was how to take over Augustus' personal role as princeps.
\end{abstract}

Keywords: Augustus; Principate; statio; birthday; omens; calendar; Tiberius

\section{AUGUSTUS AS 'FIRST EMPEROR OF ROME' AND 'FOUNDER OF THE PRINCIPATE'}

A survey of the scholarship inspired by the bimillenium of Augustus' death in 2014 has pinpointed a recent shift in scholarship whereby Augustus' own centrality to the "age of Augustus" has come into question. ${ }^{2}$ This is largely a reflection of the fact that interest has moved away from examining Augustus' formal political position. Despite this shift away from analysing the Augustan era in terms of the contribution of Augustus himself, two ways of thinking about Augustus still linger in scholarly literature - as first emperor of Rome and as founder of a new constitution, the Principate - even though neither is helpful in making sense of the political changes that took place between 44 B.C. and A.D. 14. One analysis of the 'transition from Republic to Principate', for example, unequivocally states: 'The

\footnotetext{
${ }^{1}$ I would like to thank the following for offering constructive feedback on drafts of this article: Ingo Gildenhard, Wolfgang Havener and members of the JRS Editorial Board.

${ }^{2}$ Goodman 2018a: especially 169; cf. Morrell, Osgood, Welch 2019.
} 
Principate institutionalized by Augustus in 27 BCE was vigorously cheered by the legions and by the Roman citizens of the capital; it was welcomed by large parts of the socially ruling classes and accepted by a large fraction of the senatorial aristocracy. ${ }^{3}$ Such a statement risks creating the impression that the 'Augustan Principate' sprang into being, fully formed, at a single moment. Just as writing of the 'Roman Republic' does more to obscure than illuminate our understanding of earlier periods of Roman history, ${ }^{4}$ so discussion of the 'Augustan Principate' (with a capital letter) misleadingly encourages us assume that it was a distinctive constitutional phenomenon.

This paper will explore how viewing political changes under Augustus in ways which go beyond the narrowly constitutional and how focusing upon contemporary texts rather than those written with the benefit of hindsight both better illuminate the process of experimentation by which Augustus and his contemporaries tried to make sense of his political position. It illustrates how one of the challenges faced by Tiberius was that there was no clearly defined Principate to which he could be the successor. Instead, this paper suggests that one of the main changes in the political landscape of Rome was the emergence of the idea of an age of Augustus, at the centre of which was Augustus as an individual with a unique destiny. Whilst not wishing to return to an interpretation of the age that sees Augustus as the only agent involved in shaping events and controlling Rome's political destiny, this paper will suggest that some contemporaries did make sense of their world in terms of the central part played by Augustus as an individual with a unique predestined role, and that this perception - rather than a formally defined political position - should be taken into account when thinking about Tiberius as Augustus' successor.

In the popular imagination, Augustus is known as the 'first emperor of Rome', 5 even whilst scholars nowadays tend to refocus attention upon Augustus as ciuilis princeps rather than as autocrat. ${ }^{6}$ So ingrained is the concept, though, that Karl Galinsky's nuanced discussion of Augustus is subtitled Introduction to the Life of an Emperor. ${ }^{7}$ At the same time, another key theme that persists in both popular and scholarly accounts of Augustus is the idea

\footnotetext{
${ }^{3}$ Flaig 2011: 76.
}

${ }^{4}$ Flower 2010.

${ }^{5}$ Everitt 2006; Clark 2010; Goldsworthy 2014.

${ }^{6}$ Wallace-Hadrill 1982; Galinsky 2012: 70-1. Monarchical interpretations, however, remain strong in some accounts such as Schmid 2005.

${ }^{7}$ Galinsky 2012. 
that he established the Augustan Principate. When we look back at the age of Augustus, we see clearly that it was as a result of his lengthy period in power that Rome acquired a new form of government - the Principate - and that this was one of Augustus' enduring legacies. Although Julius Caesar can be presented as the founder of the dynasty of the Caesars (notably in Suetonius' choice of starting-point for his Vitae Caesarum), and has even been touted on occasion as a rival founder of the Principate, it is Augustus whose political achievement and legacy are more commonly celebrated. ${ }^{8}$ Even though the spectre of the 'restoration of the Republic' has now been effectively exorcised, ${ }^{9}$ the idea of the Augustan Principate persists. For example, a recent comparison of Julius Caesar and Augustus as rival founders of the Principate concludes: 'it was not the monarchical powers, but above all the long-time survival of his constitution that decided the outcome in favour of Augustus' (i.e., to be regarded as founder of the Principate, rather than Julius Caesar). ${ }^{10}$ The problem of discerning what was Augustus' role in shaping politics can be illustrated by Suetonius' representation of Augustus' own aspiration to be recognised as the 'optimi status auctor' ('originator of the best state of affairs'), as expressed in the solemn edict which he records:

ita mihi saluam ac sospitem rem p. sistere in sua sede liceat atque eius rei fructum percipere, quem peto, ut optimi status auctor dicar et moriens ut feram mecum spem, mansura in uestigio suo fundamenta rei p. quae iecero.

May I be permitted in such a way to set the state safe and sound on its proper footings and to harvest the fruit of this achievement, which I seek, that I may be called the originator of the best state of affairs and that as I die I may take with me the hope that the foundations for the state which I have laid will remain in place. ${ }^{11}$

The phrase 'optimi status auctor' may be interpreted as referring to a political constitution, but, as David Wardle argues, 'this Suetonian example highlights the key usage for this passage - in prayer or vow formulae without a constitutional sense'. ${ }^{12}$ As Wardle further points out, Suetonius' subsequent explanation that Augustus was referring to a nouus status

\section{${ }^{8}$ Geiger 2018.}

${ }^{9}$ Millar 1968: 265-6; Judge 1974; Gruen 2005: 34-5; Galinsky 2012: 68.

${ }^{10}$ Geiger 2018: 86.

${ }^{11}$ Suet., Aug. 28.2, with Wardle 2014: 219; detailed analysis in Wardle 2005.

${ }^{12}$ Wardle 2005: 189. 
reflects Suetonius' own authorial view that Augustus had set in place 'a new state of affairs rather than a new constitution'. ${ }^{13}$ Similar language appears on denarii minted in 16 B.C., commemorating vows to Jupiter made on behalf of Augustus' safety 'quod per eu(m) r(es) p(ublica) in amp(liore) atq(ue) tran(quilliore) s(tatu) est' ('because through him the state is in a more expansive and peaceful condition'). ${ }^{14}$ These coins hint at the presence in Rome of inscribed monuments honouring Augustus for his role in improving the status of the res publica, whilst the highly abbreviated text on the coins suggests that the formula would have been readily recognised and was already well known in Rome. Neither the biography nor the coin legend, therefore, allows us to assume that Augustus himself was thinking in terms of constitutional reform.

This paper's first concern is to show how the word principatus changed over time, expanding on Erich Gruen's observation that its use to refer to a constitutional structure cannot be traced back to the time of Augustus: 'Augustus never occupied a post called the Principate, nor did he exercise an office to which the title princeps was attached. ${ }^{15}$ Instead, the term statio was used to refer to the position of Augustus and his successors (actual and potential) in the state and this summoned up a different vision of how the role of the princeps was understood. It then considers ways in which we can see the emergence of a new understanding of Augustus' role in the res publica, which depended upon the sense that Augustus was uniquely destined to protect Rome. Although it is clear that defining his powers legally was crucial in articulating Augustus' political role, the Augustan Principate was not just shaped by legal and constitutional innovations. There is no doubt of the relevance of the power of images and poetry to creating and developing (and in some cases challenging) political discourse around Augustus' leadership of the state, ${ }^{16}$ but what impact was made by more ephemeral experiences including omens and portents, and festival celebrations of Augustus' birthday in shaping what we might call the Augustan principate in a non-constitutional sense? This paper will focus on contemporary perceptions of Augustus' position within the res publica in order to try to explore alternative approaches to the Augustan era beyond searching for the constitutional basis of the Augustan Principate. It will

\footnotetext{
${ }^{13}$ Wardle 2014: 219.

${ }^{14}$ RIC $\mathrm{I}^{2}$ no. $358=$ Online Coins of the Roman Empire, http://numismatics.org/ocre/id/ric.1(2).aug.358 (accessed 15/02/19).

${ }^{15}$ Gruen 2005: 34; cf. already Béranger 1953: 28.

${ }^{16}$ Zanker 1988; Pandey 2018.
} 
trace the ways in which Augustus' rule became increasingly personalised, with the result that one of the main challenges faced by Tiberius in A.D. 14 was how to take over Augustus' personal role as princeps.

\section{FROM PRINCIPATUS TO STATIO}

An examination of uses of principatus makes clear that the word referring to what we would call the Principate did not emerge under Augustus, nor even in the years immediately after his death, with the first clear usage being attested only under Claudius. ${ }^{17}$ Velleius Paterculus is often regarded as one of the voices trying to make sense of the political changes around him under Tiberius, ${ }^{18}$ and, at first glance, he might be taken as decisive evidence that very soon after Augustus' death, the idea of the Augustan Principate was in common circulation. For it is in Velleius that we find the earliest instance of the word principatus in an Augustan context:

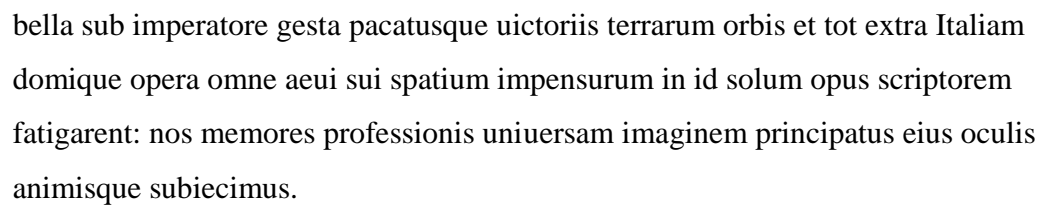

As for the wars waged under him as commander, the world pacified by his victories, and the innumerable deeds beyond Italy and at home, these would tire a writer intending to spend the entire span of his life on this task alone. But, mindful of the declared objective of my work, I have laid before the eyes and minds of my readers an overall picture of his principatus. ${ }^{19}$

The words principatus eius are commonly translated, for example, by Frederick Shipley in the Loeb edition and in Tony Woodman's commentary as 'of his principate'. ${ }^{20}$ As the context makes clear, however, this is not a reference to a constitutional settlement by Augustus, but is

\footnotetext{
${ }^{17}$ Béranger 1953: 55.

${ }^{18}$ Bloomer 2011; Hillard 2011.

${ }^{19}$ Vell. Pat. 2.89.6.

${ }^{20}$ Shipley 1924: 239; Woodman 1983: 260.
} 
rather a turn of phrase relating to his period of leadership, and there is a danger of making the phrase sound of more constitutional significance than it really is. ${ }^{21}$

To understand Velleius' use of principatus, we can draw upon earlier authors, since the word principatus existed before what we call the Principate came about in any shape. ${ }^{22}$ We can see it used in relation to the position of princeps senatus (leader of the Senate) held by M. Scaurus in Cicero's speech delivered in defence of Scaurus' son in 54 B.C. ${ }^{23}$ otherwise its earliest use appears to be by Caesar, in describing the Gallic chieftain Dumnorix: 'qui eo tempore principatum in ciuitate obtinebat ac maxime plebi acceptus erat' ('who at this time was holding onto principatus in the state and was especially popular with the people'). ${ }^{24}$ The expression then appears more regularly and evolves rapidly in the works of Cicero written in 45/44 B.C. The De natura deorum was a work written during the months leading up to Caesar's assassination, and shows uneasy reflections on the urge towards principatus in the natural world that prefigure the more extended discussion in De officiis, written in the aftermath of the Ides. At De natura deorum 2.29, Cicero offered a gloss to explain his understanding of the concept of principatus, and that he had derived it from the Greek word hegemonikon: 'principatum autem id dico, quod Graeci hegemonikon uocant, quo nihil in quoque genere nec potest nec debet esse praestantius' ('I use the term principatus as the equivalent of what the Greeks call hegemonikon, meaning that part of anything which must and ought to have supremacy in a thing of that sort'). ${ }^{25}$ Later on in the same work, Cicero used the word principatus to refer to the dominance of the sun over the stars ('sol, qui astrorum tenet principatum'). ${ }^{26}$ Given Caesar's reorganisation of the Roman calendar, with his implicit claims to control the constellations thereby, ${ }^{27}$ we might wonder whether Cicero's

${ }^{21}$ Cf. Vell. Pat. 2.124.2, where the comment 'ut occuparent eum, alii armis pugnauerunt' ('others fought with weapons to seize it' - i.e., principatus) seems to steer us away from a narrow constitutional interpretation of the word - see Woodman 1977: ad loc. for possible alternative interpretations of who the 'alii' might be.

${ }^{22}$ TLL, s.v. principatus.

${ }^{23}$ Cic., Scaur. 46.

${ }^{24}$ Caes., $B$ Gall. 1.3.5.

${ }^{25}$ Cic., Nat. D. 2.29.

${ }^{26}$ Cic., Nat. D. 2.49.

${ }^{27}$ Feeney 2007: 196-7, with reference to Cicero's joke on the rising of the constellation of the Lyre 'by decree', Plut., Vit. Caes. 59.3. 
words were entirely innocent of political resonance. By late 44 B.C., however, Cicero had begun to explore the problematic nature of principatus in the light of Caesar's assassination. In De officiis, Cicero traced how man shared with animals a natural impulse for principatus, which could play a role as the basis for the virtue of greatness of spirit:

huic ueri uidendi cupiditati adiuncta est appetitio quaedam principatus, ut nemini parere animus bene informatus a natura uelit nisi praecipienti aut docenti aut utilitatis causa iuste et legitime imperanti; ex quo magnitudo animi existit humanarumque rerum contemptio.

In addition to this desire for seeing the truth, there is a kind of impulse towards principatus, so that a spirit that is well trained by nature will not be willing to obey for its own benefit someone whose advice, teaching and commands are not just and lawful. Greatness of spirit and a disdain for human things arise as a result. ${ }^{28}$

He saw only too clearly in the case of Caesar, however, how this natural impulse had led him astray: 'declarauit id modo temeritas C. Caesaris, qui omnia iura diuina et humana peruertit propter eum, quem sibi ipse opinionis errore finxerat principatum' ('The rash behaviour of Gaius Caesar has recently made that clear: he overturned all the laws of gods and men for the sake of the principatus that he had imagined for himself in his mistaken fancy'). ${ }^{29}$ Elsewhere, Cicero returned to the theme of the corrupting potential of an excessive desire for dominance, or principatus: 'sed illud odiosum est, quod in hac elatione et magnitudine animi facillime pertinacia et nimia cupiditas principatus innascitur.' ('It is a hateful fact that loftiness and greatness of spirit all too easily give birth to wilfulness and an excessive desire for principatus' $).{ }^{30}$ For Cicero, then, principatus was both a natural impulse that could underlie one of the cardinal virtues, and yet one that might also become distorted to the detriment of the state.

${ }^{28}$ Cic., Off. 1.13 (this quotation and following trans. Atkins in Griffin 1991).

${ }^{29}$ Cic., Off. 1.26 Cf. Nepos' description of the struggle to become princeps of the world between Antony and 'Octavian', Nep., Att. 20.5, 'when both men desired to be princeps not only of the city of Rome but of the world' ('cum se uterque principem non solum urbis Romae, sed orbis terrarum esse cuperet').

${ }^{30}$ Cic., Off. 1.64. 
Returning once more to Velleius, before using principatus in an Augustan context, he had echoed Cicero's discussion of the natural impulse to dominance in referring to the desire for principatus on the part of Crassus, which motivated his desire to form an alliance with Caesar and Pompey: 'Crassus, ut quem principatum solus adsequi non poterat, auctoritate Pompei, uiribus teneret Caesaris' ('Crassus hoped that by the influence of Pompey and the power of Caesar he might achieve that principatus which he had been unable to achieve on his own'). ${ }^{31}$ In the case of Velleius' text with which we started, in referring to Augustus it may then be more accurate to translate the word principatus as 'pre-eminence' or 'leadership' rather than 'Principate'. This fits with Velleius' political outlook, which led him to focus upon Tiberius as a continuation of Republican values and military leadership, rather than upon explaining the emergence of a new political system. ${ }^{32}$

So the word principatus did not yet in A.D. 14 signify a specific constitutional settlement to which Tiberius could step up as heir and continuator; instead, what Tiberius inherited was his paterna statio:

una tamen ueluti luctatio ciuitatis fuit, pugnantis cum Caesare senatus populique Romani, ut stationi paternae succederet, illius, ut potius aequalem ciuem quam eminentem liceret agere principem.

There was, however, one wrestling match as it were in the state, of the Senate and the Roman people struggling with Caesar to induce him to succeed to his father's statio, while he on his side strove for permission to play the part of equal citizen rather than of outstanding leader. ${ }^{33}$

Velleius' choice of this military metaphor of a soldier on guard duty reflects contemporary political discourse, with Tiberius taking over from Augustus a responsibility to guard and

\footnotetext{
${ }^{31}$ Vell. Pat. 2.44.2.
}

${ }^{32}$ Marincola 2011: 135: 'there is no sense in Velleius that there was any real break between Republic and Empire; Tiberius is portrayed as the culmination of all the great generals of the Republic.' Cf. Pelling 2011: 170-2 on the theme of restoration in Velleius' accounts of Augustus and Tiberius, arguing against the view that Velleius' narrative was structured around the emergence of one-man rule.

${ }^{33}$ Vell. Pat. 2.124.2. 
protect the res publica. ${ }^{34}$ It seems likely that Augustus was the first to adopt this innovative expression to describe his position within the state, in a letter written to Gaius Caesar in A.D. 1, as recorded by Aulus Gellius, ending:

deos autem oro ut mihi quantumcumque superest temporis, id saluis nobis traducere

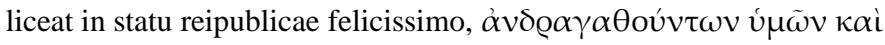

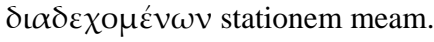

So I beseech the gods that I may be permitted to spend whatever time remains to me with us in good health and with our country enjoying a most fortunate state of affairs, while I watch you and your brother proving your mettle as you wait to take over my statio. $^{35}$

This letter, however, contains mixed messages, a sense of uncertainty, and a level of anxiety,

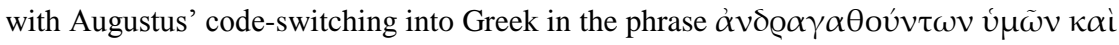

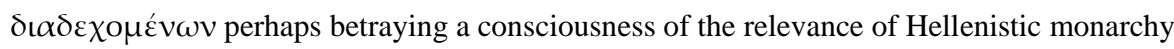
to this hope. It is interesting, however, that Augustus did not write with reference to his position as princeps (in contrast with how he writes of himself in the Res Gestae). Perhaps he thereby intended to intimate that Gaius and Lucius would be breaking new ground in Roman politics in taking over from him. On the other hand, there is a sense of unease in the contrast between Augustus' singular position ('stationem meam') and the plural references to both Gaius and Lucius. After all, given that the letter was addressed to Gaius himself, there was no real need to bring Lucius into the frame at all, and the Romans did not exactly have a good track record when it came to brothers sharing power. Furthermore, the use of the present participle in the genitive absolute $\delta\left\llcorner\alpha \delta \chi \chi \mu \varepsilon \varepsilon^{\prime} \omega \nu\right.$ raises questions about when precisely Gaius and Lucius actually become diadochoi, whilst Augustus' sense of anxiety about the current situation is reflected both in the occasion of the letter - prompted by his reaching the

\footnotetext{
${ }^{34}$ On the military tenor of the term statio, see Köstermann 1932 (especially 360-1); he also shows (435) that this continues to be the case when the term is later adopted by Christian writers such as Tertullian.

${ }^{35}$ Gell., NA 15.7.3.
} 
'climacteric' of his sixty-third birthday, which was regarded as a moment of peril - and by the over-compensating superlative description of the status rei publicae as felicissimus. ${ }^{36}$

Nor was the idea of the statio an idiosyncratic view relevant only to heirs of Augustus. In the senatus consultum de Cn. Pisone patre (SCPP), the Senate continued to perpetuate the image of the statio. In petitioning Tiberius to recover from his grief at Germanicus' death, it exhorted him to turn his attention to Drusus:

magnopere rogare et petere, ut omnem curam, quam / in duos quondam filios suos partitus erat, ad eum, quem haberet, conuerteret, / sperareq(ue) senatum eum, qu $\{\mathrm{p}\} \mathrm{i}$ [su]persit, 't'anto maior' $i$ ' curae dis immortalibus / fore, quanto magis intellegerent, omnem spem futuram paternae pro / $\mathrm{r}(\mathrm{e}) \mathrm{p}$ (ublica) stationis in uno repos $[\mathrm{i}] \mathrm{ta}<\mathrm{m}>$

The Senate make a strong plea and request that he devote all the care that he previously divided between his two sons to the one whom he still has, and the Senate hope that the immortal gods will devote all the more care to the one who remains, the more they realise that all hope for the statio which his father holds to the benefit of the commonwealth rests for the future on one person alone. ${ }^{37}$

Similarly, Velleius' final prayer for the future of Rome at the very end of his work also anticipated that Tiberius' mortal statio would pass in due course to successors:

uos publica uoce obtestor atque precor custodite, seruate, protegite hunc statum, hanc pacem, hunc principem, eique functo longissima statione mortali destinate successores quam serissimos.

On you I call and to you I pray with public voice: guard, preserve, protect this state of things, this peace, this leader, and, when he has completed the longest possible mortal statio, grant him successors at the latest time. ${ }^{38}$

What is so interesting about this choice of metaphor is that it does not evoke an image whereby the individual who is performing the statio is strongly interventionist, as shown by Valerius Maximus' use of the word on two occasions in his exempla relating to the traditional

\footnotetext{
${ }^{36}$ On the 'climacteric', see Harlow and Laurence 2017; 115-16.

${ }^{37}$ SCPP lines 126-30.

${ }^{38}$ Vell. Pat. 2.131.1-2.
} 
institutions of ancient Rome, composed during the Tiberian era: ${ }^{39}$ at 2.1.9 he described the respectful tradition of the elite youth of Rome of escorting their elders to the curia, and then keeping statio outside,_waiting for their elders within to finish their debates before then accompanying them back home:

senectuti iuuenta ita cumulatum et circumspectum honorem reddebat, tamquam maiores natu adulescentium communes patres essent. quocirca iuuenes senatus die utique aliquem ex patribus conscriptis aut propinquum aut paternum amicum ad curiam deducebant adfixique ualuis expectabant, donec reducendi etiam officio fungerentur. qua quidem uoluntaria statione et corpora et animos ad publica officia inpigre sustinenda roborabant breuique processurarum in lucem virtutum suarum uerecunda laboris meditatione ipsi doctores erant.

Youth used to render to old age a respect as ample and considerable as if the elders had been fathers in common to the young. So on a senate day the young men used to escort one of the Conscript Fathers, either a kinsman or paternal friend to the senate house, and they used to wait rooted to the doors until they could perform the further service of escorting him home. By this voluntary statio they strengthened their bodies and minds to undertake public duties energetically and by respectful practice of fatigue became themselves teachers of their virtues which were about to emerge into the light of day.

Further, at 2.2.6 he described how senators would keep their statio in the Forum Romanum, as they waited to be summoned to attend a meeting:

antea senatus adsiduam stationem eo loci peragebat, qui hodieque senaculum appellatur: nec expectabat ut edicto contraheretur, sed inde citatus protinus in curiam ueniebat.

Previously the Senate used to keep constant statio in the place which today too is called the senaculum. It did not wait to be assembled by edict but proceeded from there to the senate house immediately when summoned.

${ }^{39}$ Date of composition of Valerius Maximus: Syme 1978: 161-2; Bellemore 1989; Bloomer 1992: 1. 
Furthermore, Valerius drew attention to the exemplary value of the imperial family prominently in the preface to Book 6, in describing how Pudicitia kept a constant statio on the Palatine: 'tu Palatii columen Augustos penates sanctissimumque Iuliae genialem torum adsidua statione celebras' ('you frequent with constant statio the summit of the Palatine, the august household gods, and the most holy marriage bed of Julia').$^{40}$ Essentially, then, the idea of statio evokes an image of the princeps as someone waiting and watching for occasions on which the res publica needs help. A hint that this continued to be regarded as the ideal role for Rome's leaders emerges in one of Seneca the Younger's letters, written in 62:

saepe uidemur taedio rerum ciuilium et infelicis atque ingratae stationis paenitentia secessisse, tamen in illa latebra, in quam nos timor ac lassitudo coniecit, interdum recrudescit ambitio.

I may often seem to have retired because of being fed up with state business and regretting my hapless and thankless statio, yet in that retreat to which fear and exhaustion have thrust me, ambition from time to time breaks out again. ${ }^{41}$

His reference to his own role as having been one of a statio (albeit a hapless and thankless one) might be taken to betray how Seneca saw himself as the ideal leader of Rome, following in Augustus' footsteps, in contrast to the autocratic Nero. ${ }^{42}$

The whole idea of statio fits nicely with descriptions of the princeps as protector and saviour of the res publica, one of the central ideological principles for future generations of principes too. ${ }^{43}$ In writing of a failed coup against Tiberius, a passage which is generally thought to allude to Sejanus, Valerius Maximus gave a vivid impression of the dependence of Rome upon Tiberius for its wellbeing, describing Tiberius as 'auctor ac tutela nostrae incolumitatis' ('originator and protector of our safety'). ${ }^{44}$ The Senate further extended this special relationship between princeps and res publica to the domus Augusta more widely, in praising the army for its recognition that Rome's safety depended uniquely upon Tiberius and his family:

\footnotetext{
${ }^{40}$ Val. Max., 6.1.praef.

${ }^{41}$ Sen., Ep. 56.9.

${ }^{42}$ For subsequent development of the term, see Tac., Dial. 17.3.

${ }^{43}$ Veyne 2002-3: esp. 8.

${ }^{44}$ Val. Max., 9.11.ext.4.
} 
omnesq(ue), qui sub auspicìs et imperio principis / nostri milites essent, quam fidem pietatemq(ue) domui Aug(ustae) p'raesta'rent, eam sperare / perpetuo praestaturos, cum scirent salutem imperi nostri in eius $\operatorname{dom}^{\top} \mathrm{u}^{\top}<\mathrm{s}>$ custo/dia posita $<\mathrm{m}>\operatorname{esse}\{\mathrm{t}\}$

The Senate hopes that all who were soldiers in the service of our Princeps will continue to manifest the same loyalty and devotion to the imperial house, since they know that the safety of our empire depends on the protection of that house. ${ }^{45}$

We therefore have a coherent picture in contemporary texts that the role of Rome's leader should be one of protecting and defending the res publica. What is noteworthy, though, from Augustus' letter to Gaius onwards, is the expectation that the individuals taking over the statio from Augustus should prove themselves worthy of the responsibility. By A.D. 20, with the $S C P P$, we find that the claim to ethical and political leadership was becoming increasingly articulated as the preserve of the imperial family, in the form of the domus Augusta. ${ }^{46}$ This was an extension of an earlier tendency to mark out Augustus as an exceptional individual, to which the next section of this paper will turn, and arguably an attempt to solve the problem posed for his successors in justifying Augustus' own position as princeps in a very personal way by also creating a sense that other members of the imperial family, too, shared in distinctive ethical superiority which they were then to transmit to the rest of Roman society, in virtue of having themselves been brought up in Augustus' household. ${ }^{47}$

\section{BORN TO GREATNESS?}

If we take principatus as referring to Augustus' pre-eminence in the state, rather than to a constitutional structure, we can extend our understanding of how that pre-eminence was constructed beyond the granting of political powers and honours to him by the Senate. One of the most distinctive and innovative features of the Augustan era was the promotion of astrological symbolism and the idea that Augustus' birthday had predestined him for rule. ${ }^{48}$

\footnotetext{
45 SCPP 160-3.

46 On the development of the domus Augusta, see Millar 1993; Corbier 2001.

${ }^{47}$ Cooley 1998.

48 Schmid 2005.
} 
His exceptional destiny was allegedly apparent from the birthmarks on his body, laid out, according to Suetonius, in the pattern of the constellation Ursa Major, which was not only closely associated with myths of Jupiter, but was also regarded both as situated on the North Pole, the axis around which the universe rotated, and also as echoing the image of the cosmos itself with its seven stars paralleling seven planets. ${ }^{49}$ By the time that Suetonius composed his imperial biographies, it was clear that Augustus' greatness had been heralded by many omens, right from the moment of his birth, when the astrologer Publius Nigidius Figulus was supposed to have declared the ruler of the world to have been born, ${ }^{50}$ to the lightning-strike in his last months that was interpreted to presage his deification by creating the Etruscan word for god by melting the $\mathrm{C}$ at the start of CAESAR beneath one of his statues. ${ }^{51}$ Towards the end of the biography, from chapters 94 to 97 , Suetonius lists twenty-five omens and dreams 'by which his future greatness and perpetual good fortune could be expected and observed'. ${ }^{52}$ Chapter 94 itself is the longest in the whole biography, and throws this material into sharp relief. ${ }^{53}$ It is foreshadowed towards the start of the biography too, where Suetonius relates the strange happenings in later years that occurred at Augustus' possible birthplace near Velitrae, where a man, who ignored local scruples and slept in the room where Augustus' was said to have been born, was found flung out of bed, half-dead. ${ }^{54}$ Even though these signs of divine favour clearly owed much to hindsight, the idea that rising to imperial rule (and indeed falling from it) was a predestined phenomenon is woven through Suetonius' biographies as a whole, illustrating that the idea that emperors were born to greatness was an accepted part of Rome's political landscape by the Hadrianic period, whilst the idea of divinely sanctioned rulers had been prefigured under the Republic. ${ }^{55}$ Indeed, the whole sequence of Lives ends with

\footnotetext{
${ }^{49}$ Suet., Aug. 80; Wardle 2012: 318; Gury 2001; Cook 2018: 66-7.

${ }^{50}$ Suet., Aug. 94.5: 'affirmasse dominum terrarum orbi natum.'

${ }^{51}$ Suet., Aug. 97.2.

${ }^{52}$ Suet., Aug. 94.1: 'quibus futura magnitudo eius et perpetua felicitas sperari animaduertique posset.'

${ }^{53}$ Wardle 2014: 509.

${ }^{54}$ Suet., Aug. 6.

55 Osgood 2013: 37; Wallace-Hadrill 1983: 191-5. For Julius Caesar's divine favouritism, see Gildenhard 2011: 228-9, 358-9; Weinstock 1971: 112-27.
} 
Domitian's dream of a golden hump sprouting from his back, which Suetonius declared to be a portent that richer and happier times were at hand for the empire. ${ }^{56}$

Tales of Augustus' predestined greatness were, therefore, well established by the second century A.D., but it seems that they were also a feature of his lifetime. Some hint of future developments can be found already in the Philippics of Cicero, who must take some responsibility for providing the initial impetus towards singling out the future Augustus through his exaggerated language. His 'rhetoric of crisis', ${ }^{57}$ to use Jonathan Hall's expression, produced extremes of language that foreshadowed the language of imperial eulogy. For example, Cicero referred to the young Caesar's actions in recruiting his private armies as 'deorum immortalium beneficio, diuina animi, ingenii, consilii magnitudine' ('by gift of the immortal gods, through the divine greatness of his spirit, character and planning'). ${ }^{58}$ What Cicero did not anticipate, though, was how this language would over the coming decades become internalised within ways of speaking of the same young Caesar, now undisputed leader of Rome.

Suetonius' list of omens captures some glimpses of contemporary texts that had from early on in Augustus' pathway to power marked him out as destined for greatness. Suetonius explicitly attributed to the Theologumena by Asclepiades of Mendes ${ }^{59}$ (perhaps himself an imperial freedman) a dream about Augustus' conception coming about after a visitation by a snake experienced by his mother Atia while she was sleeping in a temple of Apollo. ${ }^{60}$ This episode is redolent of similar tales of the conception of Alexander the Great, ${ }^{61}$ and indeed the prophetic dreams associated with Augustus' birth appear to be a new phenomenon that evoked the world of Alexander the Great. This is not surprising given Asclepiades' origins at Mendes in the Nile delta region, ${ }^{62}$ but it is also suggestive of the context in which reports of such dreams may have arisen. It seems plausible that dreams about Augustus' birth presaging his world rule belong to the run-up to Actium, when Antony was casting aspersions upon his

\footnotetext{
${ }^{56}$ Suet., Dom. 23.2.

${ }^{57}$ Hall 2002: 283-5.

${ }^{58}$ Cic., Phil. 5.8.23.

${ }^{59} \mathrm{FGrH} 617$.

${ }^{60}$ Suet., Aug. 94: 'in Asclepiadis Mendetis Theologumenon libris lego.' ('I read in the books of Theologumena of Asclepiades of Mendes').

${ }^{61}$ Collins 2012.

${ }^{62}$ Weber 2000: 147-60.
} 
rival's family background, especially since an epigram by Domitius Marsus (one of Maecenas' circle) on his parentage can be dated to the period 41-31 B.C. ${ }^{63}$ It may be precisely the Hellenistic and Egyptian affiliations of Antony that prompted the inspiration for such dreams of Augustus' birth to be generated in the first place, but in any case they marked an important new way of talking about a potential ruler of Rome.$^{64}$ It is unclear how widespread such accounts were, but it is possible that they spread into visual media too, if the identification of an oval carnelian cameo now in the Hermitage Museum, St Petersburg as a depiction of Atia's encounter with the snake is correct. ${ }^{65}$

The moments of Augustus' conception and birth, therefore, were from as early as the 30s B.C. already promoted as portending his future greatness. Subsequently, the date of his birth came to be embedded into Rome's ritual year. Games to mark his birthday were first decreed in 30 B.C., then in 20 B.C., 13 B.C. and 11 B.C., and became an annual feature of the calendar from 8 B.C. ${ }^{66}$ The equestrian order also regularly celebrated his birthday at Rome. ${ }^{67}$ Augustus' birthday became more prominent in the capital in other ways too: it was the dedication date of various temples, including those of Jupiter Stator, Juno Regina, Neptune, Mars, and Apollo Sosianus, and the layout of the solar meridian on the Campus Martius may have further expressed in monumental form the idea that Augustus' birthday had cosmic significance. ${ }^{68}$

\footnotetext{
${ }^{63}$ Weber 2000: 152: Epigrammata Bobiensia 39: 'ante omnes alias felix Atia hoc ego dicor / siue hominem peperi femina siue deum' - 'I am called Atia, blessed above all other women, whether as a woman I gave birth to a man or a god' (trans. Wardle). Cf. Wardle 2014: 51617 , who points out, however, that the crucial word Atia is a textual emendation.

${ }^{64}$ On the dating of the dreams, see also Lorsch Wildfang 2000.

${ }^{65}$ Pollini 2012: 171, Fig. IV.11.

${ }^{66}$ Ludi natalicii on 23 September, decreed in 30 B.C.: Cass. Dio 51.19.2 (30 B.C.), 54.8 .5 (20

B.C.), 54.26 .2 (13 B.C.), 54.34 .1 (11 B.C.), 55.6 .6 (8 B.C.). Last in A.D. 13 - Cass. Dio
}

56.29.2. Cf. Koortbojian 2013: 175.

${ }^{67}$ Suet., Aug. 57.2: 'equites R. natalem eius sponte atque consensu biduo semper celebrarunt.' 'Roman equestrians of their own accord and by common consent always celebrated his birthday over two days.'

${ }^{68}$ Rehak 2006: ch. 4; Heslin 2007; Haselberger 2011. 
Other imperial anniversaries celebrated at Rome equally served to underline Augustus' unique role as saviour and protector of the state. ${ }^{69}$ Augustus in his Res Gestae mentioned four-yearly vows for his good health performed by consuls and priests and the games held in fulfilment of those vows (9.1); his name incorporated into the hymn of the Salii (10.1); 890 days on fifty-five occasions on which thanksgiving was offered by the Senate (4.2); the consecration of the altar of Fortuna Redux and the naming of the day on which he had returned to Rome from Syria, 12 October, as the Augustalia (11). Other texts mention annual vows on 1 January for his welfare, and libations poured to him at public and private feasts. ${ }^{70}$ The years following 9 B.C. continued to make the person of Augustus central to the city of Rome: the compital shrines at the heart of the reorganisation of the city of Rome in 7 B.C. created a special relationship between Augustus and the freedmen and slaves who were appointed as cult officials, and the month Sextilis was re-named August in 6 B.C. ${ }^{71}$ Even though Augustus was not the recipient of official state worship at Rome, his unique place in Roman religion, history and society was apparent. All of this added up to creating an overwhelming sense of Augustus' charismatic authority, something that was not entirely down to his own personality or cunning manipulation of public opinion, but something that resulted from people's own readiness to entrust their safety to him. ${ }^{72}$ Participation in religious ceremonies and rituals associated with Augustus as staged in the city of Rome would have consolidated people's perception that he was their destined leader since such activities stimulated participants' emotional and sensory engagement. ${ }^{73}$

In addition to celebrations focused around Augustus' birthday, the celebration of the ludi saeculares in 17 B.C. articulated an important stage in the development of the sense that what contemporaries were witnessing was nothing less than the dawning of a new age. ${ }^{74}$ The whole festival was preceded by rituals of purification, with distributions to the citizen body of suffimenta (substances such as sulphur and asphalt) so that they could fumigate and so purify their households, as commemorated on coinage and described in the inscribed dossier

\footnotetext{
${ }^{69}$ Feeney 2007: 184-9.

${ }^{70}$ Libations: Cass. Dio 51.19.7.

${ }^{71}$ Lott 2004.

${ }^{72}$ Flaig 2011: 72.

${ }^{73}$ Ewald and Noreña 2010: 42.

${ }^{74}$ Res Gestae 22.2, with Cooley 2009: ad loc.
} 
regulating and memorialising the games. ${ }^{75}$ Augustus, as president of the quindecimviri who were responsible for overseeing the festival on the instructions of the Sibylline Oracles, was prominent during the rituals. He shared the lead in sacrifices and prayers with his colleague Agrippa, and may even have written a letter to the quindecimviri concerning the festival's conduct. Horace's hymn composed for the occasion, and sung by a select group of girls and boys, highlighted the role of Augustus, described as the offspring of Venus and Anchises, in mediating with the gods on behalf of the Roman people, as they chanted:

And whatever the glorious descendant of Anchises and Venus supplicates of you with white oxen, let him attain, superior in war, mild to the enemy lying before him. ${ }^{76}$

In this way, the sense was created that Augustus was ushering in a new age in Rome's history, but not yet do we get the impression that he was in any key sense actually responsible for creating the saeculum. Instead, the new age was represented as being the end of a natural cycle of years marking the 'longest span of human life from birth to death' ${ }^{77}$ Whether this cycle was 100 or 110 years in length, the celebration was intended to secure prosperity for Rome and its empire for the next cycle of years, as recorded in the final lines of the Sibylline Oracles: 'Then shall this land, the land of Italy and all its peoples too, accept your yoke upon their necks, and live beneath your sway for ever more. ${ }^{, 78}$ Nevertheless, the impression is given that, although Augustus may not have created the new age, its future prosperity could only be guaranteed by his presence at the head of the state. ${ }^{79}$ Augustus and his family were

${ }^{75}$ RIC I ${ }^{2}$ no. 350. Cf. CIL 6.32323.29-36, 64-76, with Schnegg-Köhler 2002; Zos. 2.5.1.

${ }^{76}$ Hor., Carm. Saec. 49-52: 'quaeque uos bobus ueneratur albis / clarus Anchisae Venerisque sanguis, / impetret, bellante prior, iacentem / lenis in hostem.'

${ }^{77}$ Censorinus, $D N$ 17.2: 'saeculum est spatium uitae humanae longissimum partu et morte definitum.'

${ }^{78}$ Zos. 2.6.1. Cf. prayer of the quindecemviri led by Augustus, requesting success at home and abroad for the Roman people: $A E$ 1988, 21.

${ }^{79}$ Compare the sentiment in the SCPP 30-2 in referring to Germanicus' mission to the East, that certain situations in the provinces demanded the presence either of the princeps or of one of his sons: 'qui a principe nostro ex auctoritate huius ordinis ad / rerum transmarinarum statum componendum missus esset desiderantium / praesentiam aut ipsius Ti(beri) Caesaris Aug(usti) aut filiorum alterius utrius.' ('who had been dispatched by our princeps with the 
uniquely prominent in the prayer repeated several times during the rituals, since the gods were asked not just to promote the military success and prosperity of the Roman people, but also to be well-disposed towards 'me, my family and household'. ${ }^{80}$ In addition, the emphasis upon the goddesses of childbirth may have taken on particular resonance for Augustus' family, given the birth of Lucius at around the time of the games. ${ }^{81}$

Consequently, the ludi saeculares offer a good example of how Augustus organised public ceremonials in which he played a leading role. Their staging on temporary structures raised for the purpose over several nights and days and the emphasis on the participation of all members of the citizen body in the celebrations make clear that the festival must have had enormous impact upon Rome's citizen population. ${ }^{82}$ The impression was formed that Augustus was the individual upon whom Rome's successful intercession with the gods depended. Consequently, vows and prayers on behalf of Augustus' welfare reflected his importance to Rome's continuing prosperity at home and abroad. Public ritual and ceremonials at Rome had for many years elevated Augustus above his peers, but the year 9 B.C. seems in many respects to mark the beginning of a new degree of dominance, with the dedication of the Ara Pacis Augustae. Even without the controversial shadow allegedly cast upon it from the obelisk, ${ }^{83}$ the centrality of Augustus and his family to Roman public life was clear. Firstly, pax Augusta was the first of the August(an) deities to be introduced to Rome. ${ }^{84}$ Secondly, the altar was dedicated on Livia's birthday, 30 January. ${ }^{85}$ Thirdly, Augustus led the procession depicted on the life-sized reliefs; and, finally, annual sacrifices by magistrates, pontifices and Vestals ensured that the altar and its cult remained the centre of attention at least once a year. ${ }^{86}$ Before the age of electronic mass media, transitory spectacles typically

authority of this House to put overseas affairs in order, affairs which called for the presence either of Tiberius Caesar Augustus himself or of one of his two sons').

${ }^{80}$ CIL 6.32323 lines 90-9; Cooley 2006: 230-2.

${ }^{81}$ Lucius born between 14 June and 15 July: $A E$ 1981.316; Vassileiou 1984: 46-52; Hurlet 1997: 113. Adoption of Gaius and Lucius possibly on 26 June: Hurlet 1997: 428-9 n. 55. Ludi saeculares took place from 31 May to 3 June, with additional games 5-12 June.

82 Beacham 1999.

${ }^{83}$ Main lines of the debate are laid out by contributions in Haselberger 2011.

${ }^{84}$ Cooley 2006: 246-52.

${ }^{85}$ Fasti Praenestini, 30 January.

${ }^{86}$ Res Gestae 12.2.
Commented [CK2]: Have I understood the CIL reference correctly; wasn't sure about 90-9?

Commented [AC3R2]: The whole prayer is 90-99; the specific phrase is at 99 . 
leave little trace in the historical record, but unless we try to imagine the pomp and circumstance of processions, sacrifices and prayers, their sights, smells and sounds, we shall underestimate the impact of Augustus upon the inhabitants of the city of Rome.

Changes to the calendar of the province of Asia in 8 B.C., where the date of Augustus' birthday, 23 September, was officially recognised as New Year's Day in the province as part of the move towards adopting Rome's Julian calendar, illustrate how the ideas being formulated at Rome were also spreading in the Greek East. ${ }^{87}$ The proposal to introduce Augustus' birthday as New Year's Day was made on the initiative of the Roman proconsul himself, Paullus Fabius Maximus. The epigraphic dossier preserving copies of the proconsul's edict and decrees of the koinon from several cities in the province illustrates that the governor took care to couch his recommendations in non-authoritarian language, even whilst in effect giving out a set of instructions; even so, the koinon did not accept his recommendations wholesale, but made some modifications to the calendrical scheme which he had proposed in order to ensure that it was actually workable. ${ }^{88}$ We should also note his personal ties to Augustus, given that he was married to Augustus' cousin Marcia, and that her relationship to Augustus was recorded on at least one inscription in the East, at Paphos in Cyprus. ${ }^{89}$ In his edict, the governor explained the significance of Augustus' birthday as marking the moment at which the world could be rescued from its headlong rush to ruin:

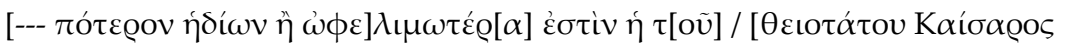

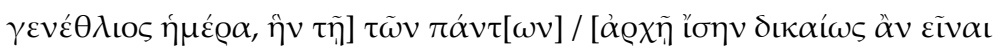

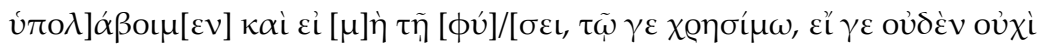

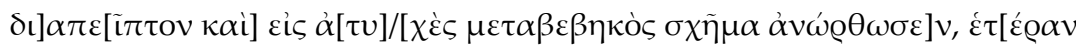

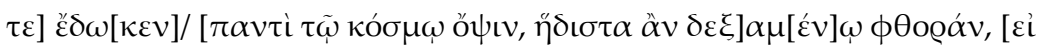

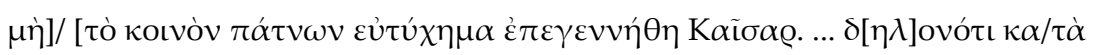

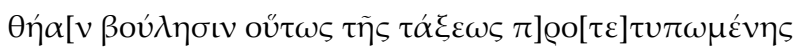

\footnotetext{
${ }^{87}$ Laffi 1967; Sherk 1969, RDGE 328-37 no. 65 (composite text); Dreyer and Engelmann 2005: 175-82; Stern 2012: 274-8, with arguments for 8 B.C. rather than 9 B.C.

${ }^{88}$ Stern 2012: 277.

${ }^{89}$ ILS 8811.
} 
whether the birthday of the most divine Caesar is more pleasurable or more advantageous, we would rightly suppose it is the same as the beginning of everything, even if not by nature, at any rate in terms of being useful, inasmuch as he put right everything which is falling to pieces and has passed into poor condition, and he gave a new look to the whole world, which would have embraced ruin most cheerfully, had not Caesar's birth supervened for the common good fortune of everything. ... quite clearly an arrangement predestined in this way according to some divine plan... ${ }^{90}$

Fabius Maximus was thus making a claim that the birth of Augustus had made a definitive difference to people's lives. ${ }^{91}$ This calendrical innovation marked a new step in the promotion of the idea that Augustus' birth date itself had predetermined his future as ruler of the world, and it may not be sheer coincidence that it was the same year that saw the institutionalisation of the ludi natalicii at Rome as an annual feature in the city's calendar. ${ }^{92}$

The overall perception of Augustus' predestined role as ruler of Rome is most clearly articulated in the astronomical poem of Manilius, whose verses summed up the significance of Augustus' birth under the zodiac sign of Libra:
Hesperiam sua Libra tenet, qua condita Roma
orbis et imperium retinet discrimina rerum,
lancibus et positas gentes tollitque premitque,
qua genitus Caesar melius nunc condidit urbem
et propriis frenat pendentem nutibus orbem.

Balance, her own sign, holds Italy: beneath it Rome and her sovereignty of the world were founded, Rome, which controls the issue of events, and which makes peoples placed in the scales both rise and fall: beneath this sign Caesar was born, who has now founded the city more auspiciously and holds the reins of a world which hangs on the nod of his command. ${ }^{93}$

\footnotetext{
${ }^{90}$ SEG 56.1233.

${ }^{91}$ Friesen 2001: 125.

${ }^{92}$ Cass. Dio 55.6.6.

${ }^{93}$ Manilius 4.773-7, following Volk 2009: 157-9; an alternative interpretation sees this passage as referring to Tiberius, though, as discussed by Lewis 2008: 314-15.
} 


\section{THE INVENTION OF THE AGE OF AUGUSTUS}

In the end, then, what this paper seeks to explore is what the Augustan principate (rather than Principate) might mean in non-constitutional terms, and how contemporaries viewed the political changes that developed over the decades of Augustus' lifetime. It analyses the ways in which power at Rome became increasingly bound up with the person of Augustus himself. We do not necessarily have to jettison all references to the 'Augustan principate' from our scholarship, but we should be more cautious in how we use the term. Overall, what we witness in Augustus' lifetime, is not so much the creation of the Augustan Principate as a new constitution, but an increasing recognition that Augustus himself was an exceptional individual, whose position in the state was supported by powers granted formally by senatorial decree and popular vote as well as informally by acclamation, but whose authority ultimately was a personal quality, supported by the gods, and predestined by birth. The personalisation of the Augustan era occurred over time, as the sense of Augustus' unique destiny, as determined by his horoscope, began to take firm hold. ${ }^{94}$ Thinking in terms of the emergence of an "age of Augustus" brings us closer to contemporary perceptions of Augustus, as shaped by the lived experience of the city of Rome, than trying to view the changes in Roman politics in a strictly constitutional framework. ${ }^{95}$

According to Suetonius, a senator in the days following Augustus' death, proposed 'ut omne tempus a primo die natali ad exitum eius saeculum Augustum appellaretur et ita in fastos referretur' ('that all time from the very day of his birth until his demise should be called the Augustan Age, and entered thus into the calendar'). ${ }^{96}$ This is entirely consistent with references made by Augustus himself in his Res Gestae to 'saeculum nostrum' ('our era', 8.5) and 'aetas mea' ('my age', 16). What Tiberius inherited in A.D. 14 was his paterna statio, but now that his father was a god, he was faced with certain problems, most of all how

${ }^{94}$ Cf. appearance of Capricorn in visual material from the Augustan era: Hölscher 2009: 326 for roof-tile with Victory flanked by two Capricorns; Barton 1995; on coins - Wardle 2014: 532 (on Suet., Aug. 94.12): earliest minted in 28 B.C. (RIC $\mathrm{I}^{2}$ no. 545); tetradrachms in Ephesos, 27-20 B.C. (RIC I $\mathrm{I}^{2} \operatorname{nos} 477,480$ ); Spanish aurei/denarii 18 or 16/15 B.C. (RIC I ${ }^{2}$ nos 124-30); Lugdunum denarii 12 B.C. (RIC $\mathrm{I}^{2}$ nos 174-5).

${ }^{95}$ On the importance of thinking in terms of the 'lived experience' of the city of Rome, in the light of the 'spatial turn' in scholarship, see Ewald and Noreña 2010.

${ }^{96}$ Suet., Aug. 100.3. 
to negotiate successfully the shift from rule by a princeps to rule within the framework of a Principate. ${ }^{97}$ As Eleanor Cowan has observed, 'the Principate was not inevitable, nor did it arrive fully-formed in terms of either its political structures or its ideological or iconographical messages'. ${ }^{98}$ One problem faced by Tiberius derived precisely from the overwhelming focus on the person of Augustus himself: how could he successfully take over a rule that was largely based upon personal authority and prestige $?{ }^{99}$ One solution was for Tiberius himself to set himself up as being somehow imbued with at least some of Augustus' special status, and contemporaries such as Strabo considered that Tiberius was 'making Augustus the model of his administration and decrees, as are his children, Germanicus and Drusus, who are assisting their father'. ${ }^{100}$ Nevertheless, Tiberius seems only too willing to pick and choose Augustan precedent to suit his purposes in different situations, ${ }^{101}$ and, it seems, was content to continue the tradition that Augustus was exceptional, refusing divine honours for himself, and trying to work with the Senate. What he did inherit, though, was the ideological principle that the princeps should above all protect the res publica, and an emerging sense that members of the domus Augusta were peculiarly suited for this responsibility as a result of their possessing virtues inherited directly through their proximity with Augustus himself. Augustus' leadership of the state was regarded as divinely predestined, and his leadership within Rome increasingly became personalised, but his ability then to pass on his individual qualities to younger members of his household both fitted traditional Roman aristocratic values concerning the transmission of virtues from father to son and also justified to whom the paterna statio should next pass.

\section{University of Warwick}

a.cooley@warwick.ac.uk

\footnotetext{
${ }^{97}$ Cf. Vout 2013.
}

${ }^{98}$ Cowan 2011b: xii.

${ }^{99}$ Geiger 2018: 78-9 points to the difficulties for Tiberius of Augustus' insistence in Res Gestae 34 on his personal auctoritas.

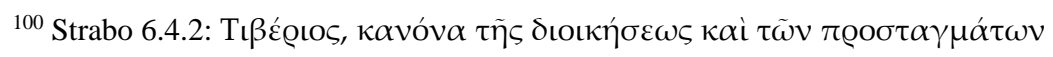

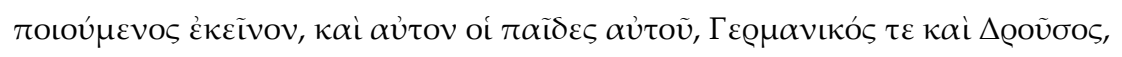

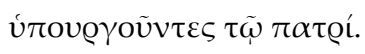

${ }^{101}$ Cowan 2009. 


\section{BIBLIOGRAPHY}

SCPP Senatus Consultum de Cn. Pisone Patre = Eck et al. 1996

Barton, T. 1995: 'Augustus and Capricorn: astrological polyvalency and imperial rhetoric', Journal of Roman Studies 85, 33-51.

Beacham, R. C. 1999: Spectacle Entertainments of Early Imperial Rome, New Haven and London.

Bellemore, J. 1989: 'When did Valerius Maximus write the Dicta et Facta Memorabilia?' Antichthon 23, 67-80.

Béranger, J. 1953: Recherches sur l'aspect idéologique du principat, Basel.

Bloomer, W. M. 2011: 'Transit admiratio: memoria, invidia, and the historian', in Cowan 2011a, 93-119.

Clark, M. D. H. 2010: Augustus, First Roman Emperor: Power, Propaganda and the Politics of Survival, Exeter.

Collins, A. 2012: 'Callisthenes on Olympias and Alexander's divine birth', Ancient History Bulletin 26, 1-14.

Cook, P. 2018: 'Embodying the Augustan in Suetonius and beyond', in Goodman 2018b, 5873.

Cooley, A. E. 1998: 'The moralizing message of the Senatus Consultum de Cn. Pisone Patre', Greece and Rome 45, 199-212.

Cooley, A. E. 2006: 'Beyond Rome and Latium: Roman religion in the age of Augustus', in C.E. Schultz and P.B. Harvey Jr (eds), Religion in Republican Italy, Cambridge, 228-52. Cooley, A. E. 2009: Res Gestae Divi Augusti. Text, Translation, and Commentary,

Cambridge.

Corbier, M. 2001: 'Maiestas domus Augustae', in G. Angeli Bertinelli and A. Donati (eds), Varia epigraphica. Atti del colloquio internazionale di epigrafia, Bertinoro, 8-10 giugno 2000, Faenza, 155-99.

Cowan, E. 2009: 'Tiberius and Augustus in Tiberian sources', Historia 58, 468-85.

Cowan, E. (ed.) 2011a: Velleius Paterculus: Making History, Swansea.

Cowan, E. 2011b: 'Introduction', in Cowan 2011a, ix-xiii.

Dreyer, B. and Engelmann, H. 2006: 'Augustus und Germanicus im ionischen Metropolis', Zeitschrift für Papyrologie und Epigraphik 158, 173-82. 
Eck, W., Caballos, A. and Fernández, F. (eds) 1996: Das Senatus Consultum de Cn. Pisone Patre, Munich.

Everitt, A. 2006: The First Emperor: Caesar Augustus and the Triumph of Rome, London. Ewald, B. C. and Noreña, C. 2010: 'Introduction' in B.C. Ewald and C. Noreña (eds), The Emperor and Rome: Space, Representation, and Ritual, Cambridge, 1-43.

Feeney, D. 2007: Caesar's Calendar: Ancient Time and the Beginnings of History, Berkeley.

Flaig, E. 2011: 'The transition from Republic to Principate: loss of legitimacy, revolution and acceptance', in J.P. Arnason and K.A. Raaflaub (eds), The Roman Empire in Context:

Historical and Comparative Perspectives, Malden MA, 67-84.

Flower, H. I. 2010: Roman Republics, Princeton and Oxford.

Friesen, S. J. 2001: Imperial Cults and the Apocalypse of John: Reading Revelation in the Ruins, Oxford.

Galinsky, K. 2012: Augustus: Introduction to the Life of an Emperor, Cambridge.

Geiger, J. 2018: 'The first emperor? Augustus and Julius Caesar as rival founders of the Principate', in Goodman 2018b, 74-86.

Gibson, A. G. G. (ed.), 2013: The Julio-Claudian Succession: Reality and Perception of the "Augustan model", Leiden and Boston.

Gildenhard, I. 2011: Creative Eloquence: The Construction of Reality in Cicero's Speeches, Oxford.

Goldsworthy, A. K. 2014: Augustus: From Revolutionary to Emperor, London.

Goodman, P. J. 2018a: 'Twelve Augusti', Journal of Roman Studies 108: 156-70.

Goodman, P. J. (ed.) 2018b: Afterlives of Augustus, AD 14-2014, Cambridge.

Griffin, M. 1991: Cicero. On Duties (with translation by E. M. Atkins), Cambridge.

Gruen, E. S. 2005: 'Augustus and the making of the Principate', in K. Galinsky (ed.), The Cambridge Companion to the Age of Augustus, Cambridge, 33-51.

Gury, F. 2001: 'Septem triones. Un thème de la prédestination dynastique à Rome', in M.

Molin (ed.), Images et représentations du pouvoir et l'ordre social dans l'antiquité. Actes du colloque d'Angers, 28-29 mai 1999, Paris, 181-8.

Hall, J. 2002: 'The Philippics', in J. M. May (ed.), Brill's Companion to Cicero: Oratory and Rhetoric, Leiden, 273-304.

Harlow, M. and Laurence, R. 2017: 'Augustus senex: old age and the remaking of the Principate', Greece and Rome 64, 115-31.

Haselberger, L. 2011: 'A debate on the Horologium of Augustus: controversy and clarifications', Journal of Roman Archaeology 24, 47-73. 
Heslin, P. 2007: 'Augustus, Domitian and the so-called Horologium Augusti', Journal of Roman Studies 97, 1-20.

Hillard, T. 2011: 'Velleius 2.124.2 and the reluctant princeps: the evolution of Roman perceptions of leadership', in Cowan 2011a, 219-51.

Hölscher, T. 1985: 'Denkmäler der Schlacht von Actium. Propaganda und Resonanz', Klio 67, 81-102.

Hurlet, F. 1997 : Les collègues du prince sous Auguste et Tibère. De la légalité républicaine à la légitimité dynastique, Rome.

Judge, E. 1974: “'Res publica restituta”: a modem illusion?', in J. A. S. Evans (ed.), Polis and Imperium: Studies in Honour of Edward Togo Salmon, Toronto, 279-311.

Köstermann, E. 1932: 'Statio principis', Philologus 87, 358-68, 430-44.

Koortbojian, M. 2013: The Divinization of Caesar and Augustus: Precedents, Consequences, Implications, New York.

Laffi, U. 1967: 'Le iscrizioni relative all'introduzione nel 9 a.C. del nuovo calendario della provincia d'Asia', Studi Classici e Orientali 16, 5-98.

Lewis, A.-M. 2008: 'Augustus and his horoscope reconsidered', Phoenix 62, 308-37.

Lorsch Wildfang, R. 2000: 'The propaganda of omens: six dreams involving Augustus', in R. Lorsch Wildfang and J. Isager (eds), Divination and Portents in the Roman World, Odense, 43-55.

Lott, J.B. 2004: The Neighborhoods of Augustan Rome, Cambridge.

Marincola, J. 2011: 'Explanations in Velleius', in Cowan 2011a, 121-40.

Millar, F. 1968: ‘Two Augustan notes', Classical Review 18, 263-6.

Millar, F. 1993: 'Ovid and the Domus Augusta: Rome seen from Tomoi', Journal of Roman Studies 83, 1-17 (= F. Millar, Rome, the Greek World, and the East, Vol. 1: The Roman Republic and the Augustan Revolution (ed. H. M. Cotton and G. M. Rogers). Chapel Hill, 2002, 321-49).

Morrell, K., Osgood, J. and Welch, K. (eds) 2019: The Alternative Augustan Age, Oxford. Osgood, J. 2013: 'Suetonius and the succession to Augustus', in Gibson 2013, 19-40. Pandey, N. B. 2018: The Poetics of Power in Augustan Rome: Latin Poetic Responses to Early Imperial Iconography, Cambridge.

Pelling, C. 2011: 'Velleius and biography: the case of Julius Caesar', in Cowan 2011a 15776.

Pollini, J. 2012: From Republic to Empire: Rhetoric, Religion, and Power in the Visual Culture of Ancient Rome, Norman. 
Rehak, P. 2006: Imperium and Cosmos: Augustus and the Northern Campus Martius (ed. J.

G. Younger), Madison.

Schmid, A. 2005: Augustus und die Macht der Sterne. Antike Astrologie und die Etablierung der Monarchie in Rom, Cologne.

Schnegg-Köhler, B. 2002: Die augusteischen Säkularspiele, Munich and Leipzig.

Sherk, R. K. 1969: Roman Documents from the Greek East. Senatus Consulta and Epistulae to the Age of Augustus, Baltimore.

Shipley, F. W. 1924: Velleius Paterculus and $\div$ Res Gestae divi Augusti, Cambridge MA.

Stern, S. 2012: Calendars in Antiquity: Empires, States, and Societies, Oxford.

Syme, R. 1978: History in Ovid, Oxford.

Vassileiou, A. 1984 : 'Caius ou Lucius Caesar proclamé princeps juventutis par l'ordre équestre', in H. Walter (ed.), Hommages à Lucien Lerat, 2 vols, Paris, 2.827-39.

Veyne, P. 2002-3: 'Qu'était-ce qu'un empereur romain? Dieu parce qu'empereur', Diogène 199, 3-25.

Volk, K. 2009: Manilius and his Intellectual Background, Oxford.

Vout, C. 2013: 'Tiberius and the invention of succession', in Gibson 2013, 59-77.

Wallace-Hadrill, A. 1982: 'Civilis princeps: between citizen and king', Journal of Roman Studies 72, 32-48.

Wallace-Hadrill, A. 1983: Suetonius: The Scholar and his Caesars, London.

Wardle, D. 2005: 'Suetonius and Augustus' "programmatic edict"', Rheinisches Museum für Philologie 148, 181-201.

Wardle, D. 2012: 'Suetonius on Augustus as god and man', Classical Quarterly 62, 307-26. Wardle, D. 2014: Suetonius: Life of Augustus, Oxford.

Weber, G. 2000: Kaiser, Träume und Visionen in Prinzipat und Spätantike, Stuttgart.

Weinstock, S. 1971: Divus Julius, Oxford.

Woodman, A.J. 1977: Velleius Paterculus: The Tiberian Narrative (2.94-131), Cambridge. Woodman, A.J. 1983: Velleius Paterculus: The Caesarian and Augustan Narrative (2.4193), Cambridge.

Zanker, P. 1988: The Power of Images in the Age of Augustus (trans. A. Shapiro), Ann Arbor. 